Article

\title{
Glass Polyalkenoate Cements Designed for Cranioplasty Applications: An Evaluation of Their Physical and Mechanical Properties
}

\author{
Basel A. Khader ${ }^{1}$, Declan J. Curran ${ }^{1}$, Sean Peel ${ }^{2}$ and Mark R. Towler ${ }^{1, *}$ \\ 1 Department of Mechanical \& Industrial Engineering, Ryerson University, Toronto, ON M5B 2K3, Canada; \\ basel.khader@ryerson.ca (B.A.K.); curran@ryerson.ca (D.J.C.) \\ 2 Division of Oral \& Maxillofacial Surgery \& Anaesthesia, Faculty of Dentistry, University of Toronto, Toronto, \\ ON M5G 1G6, Canada; Sean.Peel@dentistry.utoronto.ca \\ * Correspondence: mtowler@ryerson.ca; Tel.: +1-416-979-5000 (ext. 4518)
}

Academic Editor: James Kit-hon Tsoi

Received: 17 February 2016; Accepted: 18 March 2016; Published: 25 March 2016

\begin{abstract}
Glass polyalkenoate cements (GPCs) have potential for skeletal cementation. Unfortunately, commercial GPCs all contain, and subsequently release, aluminum ions, which have been implicated in degenerative brain disease. The purpose of this research was to create a series of aluminum-free GPCs constructed from silicate $\left(\mathrm{SiO}_{2}\right)$, calcium $(\mathrm{CaO})$, zinc $(\mathrm{ZnO})$ and sodium $\left(\mathrm{Na}_{2} \mathrm{O}\right)$-containing glasses mixed with poly-acrylic acid (PAA) and to evaluate the potential of these cements for cranioplasty applications. Three glasses were formulated based on the $\mathrm{SiO}_{2}-\mathrm{CaO}-\mathrm{ZnO}-\mathrm{Na}_{2} \mathrm{O}$ parent glass (KBT01) with $0.03 \mathrm{~mol} \%$ (KBT02) and $0.06 \mathrm{~mol} \%$ (KBT03) germanium $\left(\mathrm{GeO}_{2}\right)$ substituted for $\mathrm{ZnO}$. Each glass was then mixed with $50 \mathrm{wt} \%$ of a patented $\mathrm{SiO}_{2}-\mathrm{CaO}-\mathrm{ZnO}$-strontium (SrO) glass composition and the resultant mixtures were subsequently reacted with aqueous PAA (50 wt \% addition) to produce three GPCs. The incorporation of Ge in the glass phase was found to result in decreased working (142 s to $112 \mathrm{~s}$ ) and setting ( $807 \mathrm{~s}$ to $448 \mathrm{~s}$ ) times for the cements manufactured from them, likely due to the increase in crosslink formation between the Ge-containing glasses and the PAA. Compressive $\left(\sigma_{\mathrm{c}}\right)$ and biaxial flexural $\left(\sigma_{\mathrm{f}}\right)$ strengths of the cements were examined at 1,7 and 30 days post mixing and were found to increase with both maturation and Ge content. The bonding strength of a titanium cylinder (Ti) attached to bone by the cements increased from $0.2 \mathrm{MPa}$, when placed, to $0.6 \mathrm{MPa}$, after 14 days maturation. The results of this research indicate that Germano-Silicate based GPCs have suitable handling and mechanical properties for cranioplasty fixation.
\end{abstract}

Keywords: cranioplasty fixation; germanium; glass polyalkenoate cemets; titanium miniplate; compressive strength; biaxial flexural strength; tensile strength; ovis aries bone

\section{Introduction}

Titanium miniplates and screws are used to repair defects in cranioplasty surgeries [1,2]. While these materials can be secured to the surrounding bone using calcium phosphate cements, success has been limited due to the characteristic brittleness of such materials [3,4], meaning that they are unable to resist the forces applied during installation [5]. Poly-methylmethacrylate (PMMA) is often used in cranioplasty but also has limited success; it can cause an impairment of the body's natural defenses, leaving patients susceptible to infection [6,7]. Almost 7\% of PMMA alloplastic cranioplasties suffer some form of displacement and/or fracture [7-18]. Additionally, PMMA has a high curing exotherm of up to $120^{\circ} \mathrm{C}$, which can result in necrosis of healthy bone tissue [6], leading to the loosening of the prosthesis [19]; a problem exacerbated by PMMA's lack of chemical adhesion to bone [20].

Although they have not been used clinically in cranioplasty, Glass Polyalkenoate Cements (GPCs) have potential in this space as, unlike PMMA, they chemically bond with bone. Though the use of 
GPCs has been restricted to dental [21] and ear, nose and throat (ENT) applications [22,23], attempts have been made to tailor these materials as orthopedic adhesives. For example, titanium has been substituted for silicon in the glass phase of GPCs in order to improve the cement's mechanical and biological properties [24]. Zinc and silver ions have been added to the glass phase of GPCs because of their antimicrobial activity [25], and strontium ions $\left(\mathrm{Sr}^{2+}\right)$ have been substituted for calcium ions $\left(\mathrm{Ca}^{2+}\right)$ in order to increase radiopacity of the cement and stimulate bone formation around the implantation site [26-28]. Germanium (Ge) adopts the role of a network former when incorporated into an ionomer glass, and is theoretically capable of isomorphically replacing $\mathrm{Si}$ in the network [29]. Germanium based glasses have previously been investigated by Dickey et al. [30-32] who reported that glass reactivity decreased with Ge incorporation, resulting in GPCs with extended working times of up to $10 \mathrm{~min}$, setting times between 14 and $36 \mathrm{~min}$, and compression strengths in surplus of $30 \mathrm{MPa}$ after 30 days maturation [30]. Ge was also incorporated into borate-based ionomer glasses (BGG) by Zhang et al. [32,33] who reported that its presence increased handling properties of the resultant GPCS formulated from them [32]. This paper expands partly on Dickey and Zhang's work by investigating the applicability of germano-silicate glasses as components in GPCs for cranioplasty applications. We also build upon the authors own previous work on zinc silicate-based GPCs by evaluating the effect on the physical and mechanical properties of these GPCs by incrementally replacing the Zn in the glass component with Ge [6,34].

\section{Materials and Methods}

\subsection{Glass Synthesis}

Three glass compositions, KBT01, KBT02 and KBT03, were formulated. The control, KBT01, was a $\mathrm{SiO}_{2}-\mathrm{CaO}-\mathrm{ZnO}-\mathrm{Na}_{2} \mathrm{O}$ glass; $\mathrm{KBT02}$ and $\mathrm{KBT} 03$ contain incremental concentrations of Ge added at the expense of $\mathrm{Zn}$ (Table 1). Glasses were prepared by weighing out appropriate amounts of analytical grade reagents and ball milling $(1 \mathrm{~h})$. Each mix was then oven dried $\left(100^{\circ} \mathrm{C}, 1 \mathrm{~h}\right)$ and fired $\left(1500{ }^{\circ} \mathrm{C}\right.$, $1 \mathrm{~h}$ ) in a pure Silica ceramic crucible and shock quenched into water. The resulting frit was dried, ground and sieved to retrieve a glass powder with a maximum particle size of $<45 \mu \mathrm{m}$.

Table 1. KT Glass compositions (mol \%).

\begin{tabular}{cccccc}
\hline Nomenclature & $\mathrm{SiO}_{\mathbf{2}}$ & $\mathrm{CaO}$ & $\mathrm{ZnO}$ & $\mathrm{Na}_{\mathbf{2}} \mathrm{O}$ & $\mathbf{G e O}_{\mathbf{2}}$ \\
\hline KBT01 & 0.50 & 0.10 & 0.30 & 0.10 & 0 \\
KBT02 & 0.50 & 0.10 & 0.27 & 0.10 & 0.03 \\
KBT03 & 0.50 & 0.10 & 0.24 & 0.10 & 0.06 \\
\hline
\end{tabular}

A patented Sr-CaO-ZnO-SiO2 (BT101) glass (Table 2) [13,34] was mixed with each KBT glass for the fabrication of the GPC at a 50:50 ratio.

Table 2. BT101 glass composition ( $\mathrm{mol} \%)[13,34]$.

\begin{tabular}{ccccc}
\hline Nomenclature & $\mathrm{SiO}_{2}$ & $\mathrm{CaO}$ & $\mathrm{ZnO}$ & $\mathrm{SrO}$ \\
\hline $\mathrm{BT101}$ & 0.48 & 0.12 & 0.36 & 0.04 \\
\hline
\end{tabular}

Polyacrylic Acids (PAA)

Advanced Healthcare Limited (Kent, UK) supplied the PAA $\left(M_{\mathrm{W}}, 213,000\right)$. The acid was freeze-dried and ground and sieved to contain a maximum particle size of $<45 \mu \mathrm{m}$. 


\subsection{Glass Characterization}

\subsubsection{Network Connectivity (NC)}

The network connectivity of the glasses was calculated using Equation (1) [6] considering that $\mathrm{SiO}_{2}$ and $\mathrm{GeO}_{2}$ acted as network formers and $\mathrm{CaO}, \mathrm{ZnO}$ and $\mathrm{Na}_{2} \mathrm{O}$ as network modifiers.

$$
\mathrm{NC}=\frac{\mathrm{No}: \mathrm{BOs}-\mathrm{No}: \text { NBOs }}{\text { Total No : Bridging species }}
$$

where NC = Network Connectivity, $\mathrm{BO}=$ Bridging Oxygens, $\mathrm{NBO}=$ Non-Bridging Oxygens .

\subsubsection{Powder X-ray Diffraction (XRD)}

XRD patterns were collected using a PANanlytical X'Pert PRO (PANanlytical Inc., St Laurent, QC, Canada). Glass powder samples were attached to a stainless steel disc using a $20 \mathrm{~mm}$ glass slide. The powder compacts were then placed in the X-ray Diffractometer and scanned in the range $10^{\circ}<2 \theta<80^{\circ}$, at scan step size $0.05^{\circ}$ and step time of $10 \mathrm{~s}$. A generator voltage of $45 \mathrm{kV}$ and a tube current of $40 \mathrm{~mA}$ were employed using $\mathrm{Cu} k \alpha \mathrm{X}$-ray source.

\subsubsection{Particle Size Analysis (PSA)}

Particle size analysis was performed using a Coulter Ls 100 Fluid module Particle size analyzer (Beckman Coulter, Fullerton, CA, USA). The glass powder samples were evaluated in the range of 0-950 $\mu \mathrm{m}$ with a run length of $60 \mathrm{~s}$. The suspension fluid used in this case was glycerol and was used at a temperature of $37^{\circ} \mathrm{C}$. The relevant volume statistics were calculated on each glass.

\subsection{Cement Characterization}

\subsubsection{Cement Preparation}

Cements were prepared by first mixing each of the KBT series of glasses $(<45 \mu \mathrm{m}$; un-annealed) with BT101 glass (un-annealed) at a 1:1 ratio and then combining that mixture with PAA and distilled water on a glass plate at a powder to liquid (P:L) ratio of $1: 1$ using $1 \mathrm{~g}$ of glass powder $(0.5 \mathrm{~g}$ of KBT and $0.5 \mathrm{~g}$ BT101) and a $50 \mathrm{wt} \%$ solution of PAA ( $0.5 \mathrm{~g}$ of acid and $0.5 \mathrm{~mL}$ of water). The same nomenclature (i.e., KBT01, KBT02 and KBT03) were used for the cements as for the primary glass composition that they were formulated from.

\subsubsection{Handling Characteristics ( $T_{\mathrm{w}}$ and $T_{\mathrm{s}}$ )}

The cement working time $\left(T_{\mathrm{w}}\right)$, measured in ambient temperatures using a stopwatch, was defined as the period of time from the start of mixing during which it was possible to manipulate the material without having an adverse effect on its properties [35].

The setting time of the cements was measured in accordance with ISO9917 [36]. An empty mould was placed on aluminum foil and filled to a level surface with the freshly mixed cement. Sixty seconds after mixing the entire assembly was placed on a metal block $(8 \mathrm{~mm} \times 75 \mathrm{~mm} \times 100 \mathrm{~mm})$ in an oven maintained at $37^{\circ} \mathrm{C}$. Ninety seconds after mixing, a Vicat needle indenter (mass, $400 \mathrm{~g}$ ) was lowered onto the surface of the cement. The needle was allowed to remain on the surface for five seconds, the indent was then observed and the process repeated every thirty seconds until the needle failed to make a complete circular indent when viewed at $\times 2$ magnification. The net setting time of three tests was recorded.

\subsection{Scanning Electron Microscopy and Energy Dispersive X-ray Analysis (SEM-EDX)}

Backscattered electron (BSE) imaging was carried out with a JEOL Co. JSM-6380LV (JEOL Ltd., Tokyo, Japan). Compositional analysis was performed with an EDX Genesis Energy-Dispersive 
Spectrometer. All EDX spectra were collected at $20 \mathrm{kV}$ using a beam current of $26 \mathrm{nA}$. Quantitative EDX spectra were subsequently converted into relative concentration data.

\subsection{Mechanical Properties}

\subsubsection{Compressive Strength}

The compressive strengths $\left(\sigma_{\mathrm{c}}\right)$ of five cement samples of each formulation were evaluated in ambient air $\left(23 \pm 1{ }^{\circ} \mathrm{C}\right)$ according to ISO9917 [36]. Samples were tested after 1, 7 and 30 days using an Instron Universal Testing Systems (Instron Corp, Norwood, MA, USA) fitted with a $\pm 2 \mathrm{kN}$ load cell at a crosshead speed of $1 \mathrm{~mm} \cdot \mathrm{min}^{-1}$. The moulds, $4 \mathrm{~mm} \varnothing$, by $6 \mathrm{~mm}$ height in line with ISO9917 [36], were filled to excess with freshly mixed cement then covered with acetate sheet. The mould/cement/acetate constructs were then sandwiched between two stainless steel plates, clamped and incubated $\left(37^{\circ} \mathrm{C}, 1 \mathrm{~h}\right)$. The constructs were subsequently unclamped and excess flash around the moulds was removed using 1200 grit silicon carbide paper. Once ground the samples were de-moulded, placed in distilled water and incubated in water $\left(37^{\circ} \mathrm{C}\right)$ for 1,7 and 30 days. Compressive strength, $\sigma_{\mathrm{c}}$, was calculated according to Equation (2) [36]:

$$
\sigma_{c}=\frac{4 \rho}{\pi d^{2}}
$$

where $\rho=$ maximum applied load $(\mathrm{N}), d=$ diameter of sample $(\mathrm{mm})$.

\subsubsection{Biaxial Flexural Strength}

Sixty seconds after mixing commenced for each cement, rubber moulds ( $8 \mathrm{~mm} \varnothing, 2 \mathrm{~mm}$ thick) were filled to excess with cement and placed between 2 stainless steel plates, clamped, and incubated $\left(37^{\circ} \mathrm{C}, 1 \mathrm{~h}\right)$. The samples were subsequently de-moulded and incubated in distilled water for 1,7 and 30 days. The biaxial flexural strength $\left(\sigma_{\mathrm{f}}\right)$ of the cements was determined in a similar fashion to that of Williams et al. [37] which uses three support bearings on the test jig fixed to an Instron Universal Testing Systems (Instron Corp, Norwood, MA, USA) apparatus using a load cell of $1 \mathrm{kN}$. Testing was performed at a crosshead speed of $1 \mathrm{~mm} \cdot \mathrm{min}^{-1}$. Five samples for each cement formulation and incubation time were tested. $\sigma_{\mathrm{f}}$ was calculated according to Equation (3) [37].

$$
B F S=\frac{\rho(N)}{t^{2}}\{0.63 \operatorname{In}(r / t)+1.156\}
$$

where $\rho=$ fracture load $(\mathrm{N}), t=$ sample thickness $(\mathrm{mm}), r=$ radius of the support diameter $(\mathrm{mm})$.

\subsection{Adhesive Properties}

\subsubsection{Sample Preparation}

To reflect the clinical situation as closely as possible, the adhesive properties of each of the GPCs to a titanium alloy (McMaster Carr, Aurora, OH, USA) were determined using a method comparable to ASTM B348 [38]. Figure 1A,B illustrates the materials used in the construction of the test rig. A layer of the GPC (KBT01, KBT02 and KBT03) was applied to a $19.05 \mathrm{~mm}$ diameter cylinder of titanium alloy (McMaster Carr, Aurora, OH, USA), which was then attached to both fresh ovis aries cranial bone and titanium plate (ASTM B265) [39]. Figure 1C displays a layer of one of the GPCs, Figure 1D shows the Ti and bone samples used and Figure $1 \mathrm{E}$ is the anchor that is screwed into the threaded center of the Ti cylinder. Five specimens were prepared for each cement composition. Materials were then left to mature $\left(1 \mathrm{~h}, 37^{\circ} \mathrm{C}\right)$ before being submerged in a single container of distilled water $\left(37^{\circ} \mathrm{C}\right)$. The procedure was repeated for samples submerged for 1, 7, and 14 days. 


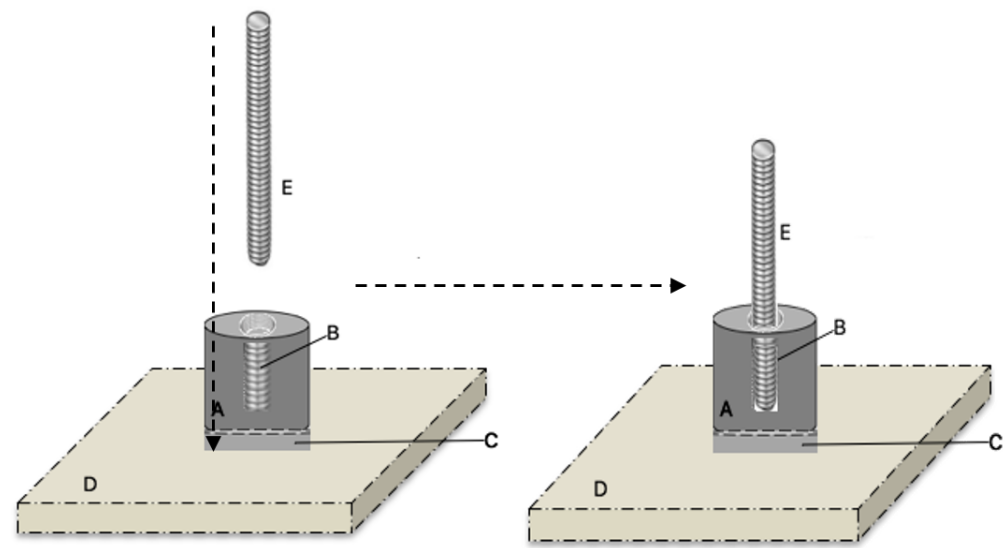

(a)

(b)

Figure 1. (A) displays the Ti Cylinder; (B) shows the thread in the center. (A) and (B) illustrate the materials used in the construction of the test rig; (C) displays a layer of one of the GPCs; (D) shows the $\mathrm{Ti}$ and bone samples used; (E) is the anchor that is screwed into the threaded center of the Ti cylinder. (a) The Ti cylinder with a layer of cement attached to the center of the Ti and bone samples, then stored in water for 1, 7 and 14 days; (b) After storage, the anchor was screwed into the Ti cylinder prior to testing.

\subsubsection{Adhesive Test}

Following maturation in distilled water, the constructs in Figure 1 were individually placed inside a hollow aluminum tube $(203 \mathrm{~mm} \times 203 \mathrm{~mm}$ with a $25 \mathrm{~mm}$ hole drilled through the top; Figure 2) with the Ti cylinder penetrating the hole. The top of the cylinder was then attached to the upper platen of an Instron Universal Testing System (Instron Corp, Norwood, MA, USA) fitted with a $\pm 2 \mathrm{kN}$ load cell. The upper platen was moved upward at a crosshead speed of $1 \mathrm{~mm} \cdot \mathrm{min}^{-1}$. The test was performed in ambient air $\left(23 \pm 1{ }^{\circ} \mathrm{C}\right)$. Samples were tested at $t=0$ and after 1,7 and 14 days and converted from Force $(\mathrm{N})$ into tensile strength using Equation (4) below.

$$
\sigma=F / A
$$

where $\rho$ is the bond strength (MPa), $F$ is the maximum force applied $(\mathrm{N})$ and $A$ is the bonded area $\left(\mathrm{mm}^{2}\right)$.

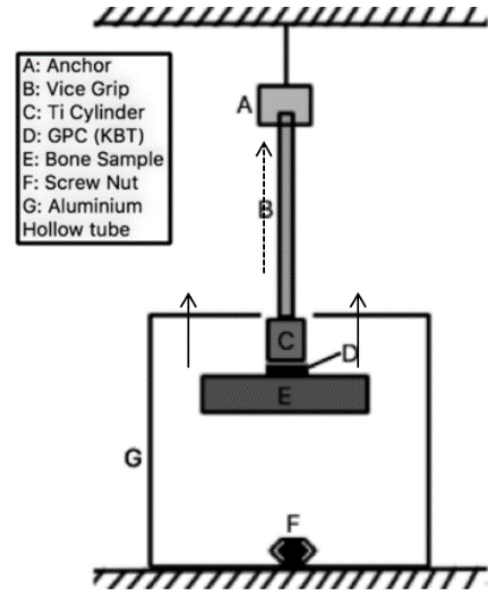

(a)

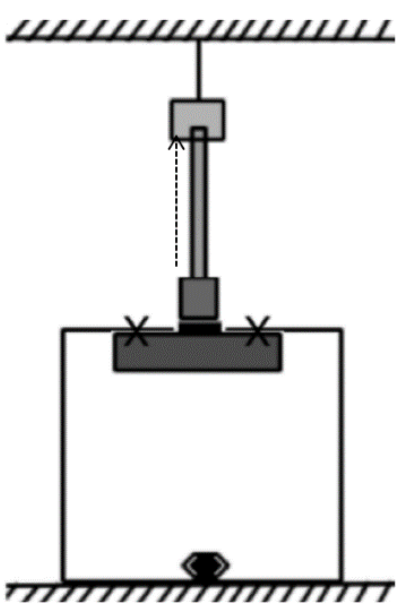

(b)

Figure 2. Bond Strength Test. (a) The start of the test; (b) The bone samples hit equally flat on the $X$ points for both sides, the construct is elevated at $1 \mathrm{~mm} / \mathrm{min}$ then the tensile bonding test begins and continues upwards until the failure occurs. 


\subsection{Ion-Release}

The concentrations of $\mathrm{Si}, \mathrm{Zn}, \mathrm{Sr}, \mathrm{Na}, \mathrm{Ge}$ and $\mathrm{Ca}$ ions released from the cements were determined by analyzing the water extracts in which samples of each set cement were stored using a Perkin Elmer atomic absorption spectrometer 800 (AAS800, Perkin Elmer, Waltham, MA, USA). 10 mL aliquots of deionized water were kept at $37^{\circ} \mathrm{C}$ in lidded containers. Samples $(n=5)$ of each cement $(8 \mathrm{~mm} \varnothing, 2 \mathrm{~mm}$ thick) were then stored for 1, 7 and 30 days in water. Following removal of cement samples from their aliquots, a 1:10 dilution of the storage water was made using purified water. Calibration standards for $\mathrm{Si}, \mathrm{Ge}, \mathrm{Ca}, \mathrm{Zn}, \mathrm{Na}$ and $\mathrm{Sr}$ elements were prepared from a stock solution on a gravimetric basis. Five target calibration standards were prepared for each ion with 0.1, 0.3, 0.5, 0.7 and 1.0 part per million (ppm) concentrations with distilled water was used as a blank. Samples for $\mathrm{Ge}, \mathrm{Ca}, \mathrm{Zn}, \mathrm{Na}$ and Sr ion analysis were diluted in a ratio of 1:10; that is, each $1 \mathrm{~mL}$ of concentrated sample was mixed with $10 \mathrm{~mL}$ of distilled water while samples for $\mathrm{Si}$ analysis were diluted in a ratio of 1:30. A pilot study was conducted to determine the appropriate ratio for dilution of all elements. The optimal working conditions are listed in Table 3.

Table 3. Operating parameters for AAS.

\begin{tabular}{ccccccc}
\hline Parameters & $\mathbf{S i}$ & $\mathbf{Z n}$ & $\mathbf{C a}$ & $\mathbf{N a}$ & $\mathrm{Sr}$ & $\mathbf{G e}$ \\
\hline Lamp current $(\mathrm{mA})$ & 5 & 5 & 10 & 5 & 10 & 10 \\
Wavelength $(\mathrm{nm})$ & 251.6 & 213.9 & 239.9 & 330.2 & 460.7 & 265.16 \\
\hline
\end{tabular}

\subsection{Micro-CT Analysis}

Radiopacity of the cements were determined and compared to a cortical bone standard using a General Electric Healthcare explore Locus SP microCT scanner (Milwaukee, WI, USA). An initial scan was performed, giving an overall X-ray image from which an area of focus was then selected for scanning at full resolution $(30 \mu \mathrm{m})$. Each of the KBT cement samples were paired with an SP3 calibration standard and placed into a full resolution scan. Images were then reconstructed and the density of the cement samples was measured using affiliated software.

\subsection{Statistical Analysis}

One-way analysis of variance (ANOVA) was used to analyze the data for handling and mechanical properties. A Post hoc Bonferroni test was used to compare the relative means and to report the statistically significant differences when $p<0.05$. Statistical analysis was performed using SPSS software (IBM SPSS statistics 21, IBM Corp., Armonk, NY, USA).

\section{Results and Discussion}

\subsection{Glass Characterization}

X-ray Diffraction (XRD)

XRD was performed to determine whether any crystalline phases were present within the KBT glasses (Figure 3). The BT101 glass was sourced from a batch previously confirmed to be amorphous [27].

\subsection{Particle Size Distribution Analysis (PSA)}

All glasses when evaluated by particle size analysis, return a d50 value of between $8.32 \mu \mathrm{m}$ and 8.69 Particle size of the glass phase will impact both rheology and mechanical properties of GPCs formulated from them; for example, increases in the surface area of the glass component will reduce setting time [40] and likely increase compressive strength [40]. However, the comparable particle sizes between sample sets in the glasses herein would not be responsible for any recorded changes in 
setting chemistry and so it is fair to conclude that any measurable changes in handling and mechanical properties of the cements being made from these glasses would be related to the chemistry of the glass phase, rather than any differences in physicality.

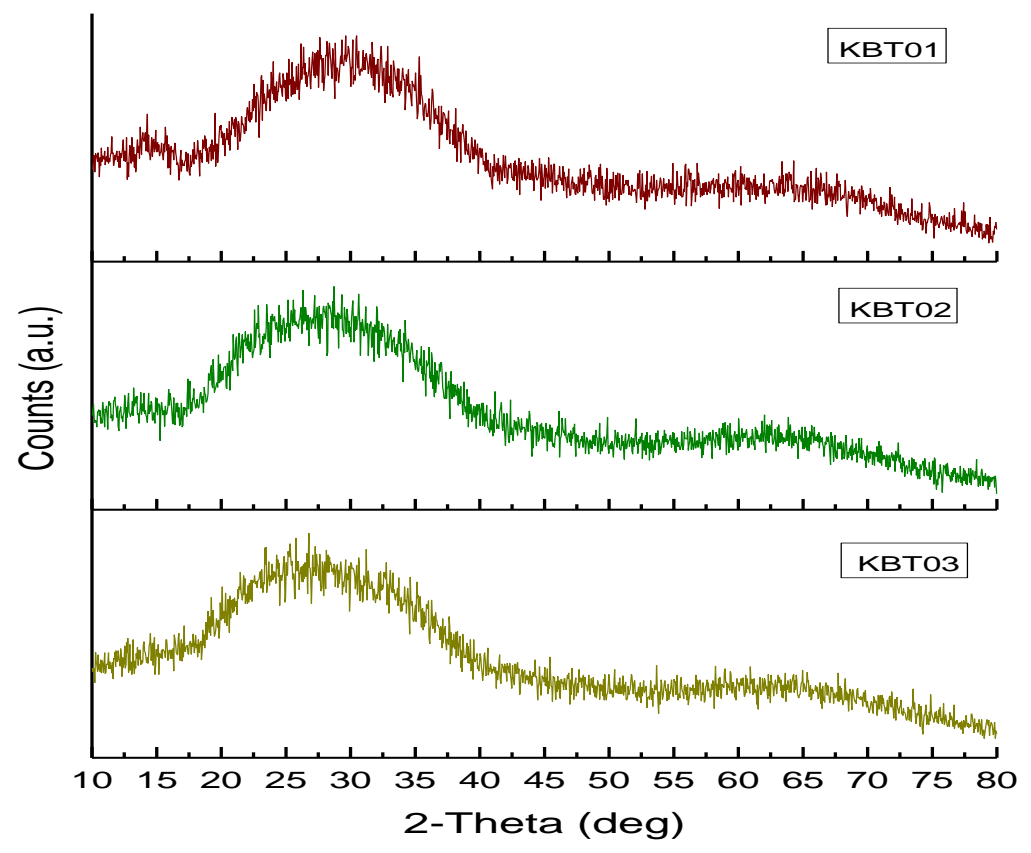

Figure 3. XRD patterns of the formulated glasses (KBT) series.

\subsection{Scanning Electron Microscopy and Energy Dispersive X-ray Analysis (SEM-EDX)}

Each glass was examined by SEM (Figure 4a-c). The KBT01 (a), KBT02 (b) and KBT03 (c) glasses were all reported to have a similar particle size distribution (d50), also the SEM imaging show that the particles are not spherical which explains some of the variation in particle size.

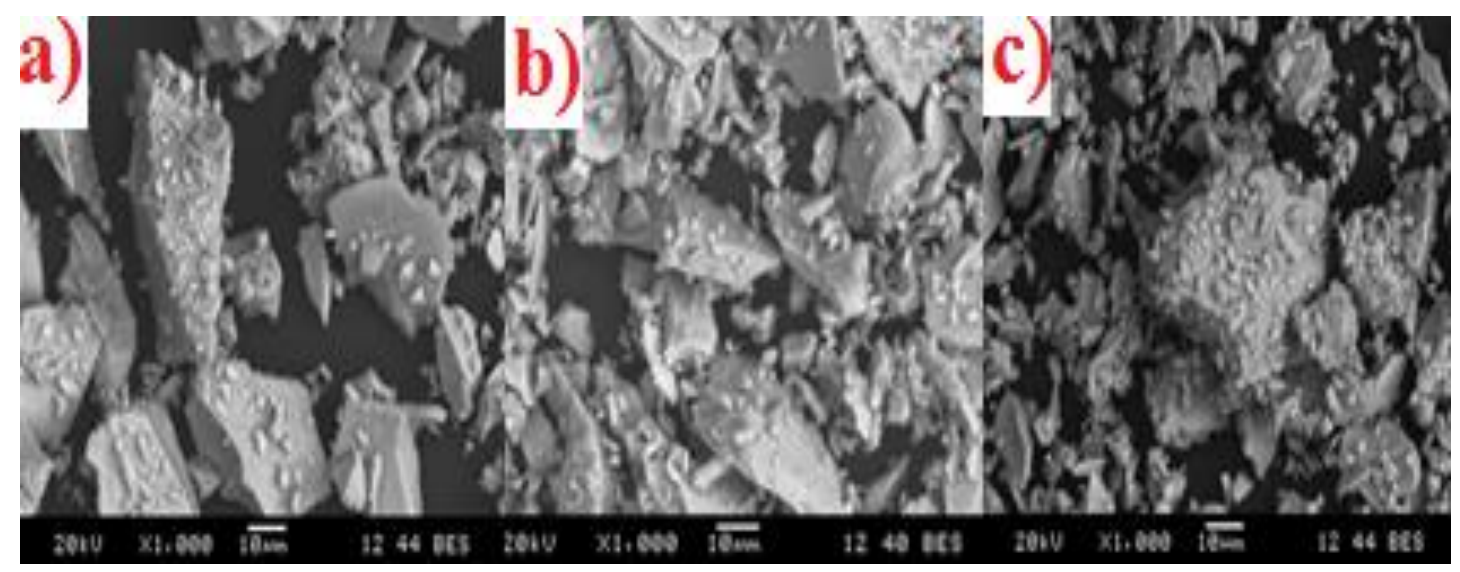

Figure 4. SEM micrographs. (a) KBT01; (b) KBT02; (c) KBT03.

EDX was performed during microscopy to confirm that the ion contents incorporated in the starting mixtures for glass firing were present in comparable amounts in the glasses (Table 4) formulated from them. 
Table 4. Composition in wt \% as verified by EDX.

\begin{tabular}{cccc}
\hline Composition & KBT01 & KBT02 & KBT03 \\
\hline $\mathrm{O}$ & 44.5 & 48.1 & 44.1 \\
$\mathrm{Si}$ & 18.3 & 17.7 & 18.2 \\
$\mathrm{Ca}$ & 2.8 & 2.5 & 2.8 \\
$\mathrm{Zn}$ & 26.5 & 22.1 & 22.1 \\
$\mathrm{Na}$ & 7.9 & 7.5 & 7.6 \\
$\mathrm{Ge}$ & - & 2.1 & 5.2 \\
\hline
\end{tabular}

\subsection{Calculation of Network Connectivity}

Calculation of Network Connectivity for the KBT and BT101 glasses as shown in Table 5.

Table 5. Calculation of Network Connectivity for all glasses. (NF) network former and (NM) network modifier.

\begin{tabular}{cccccccc}
\hline \multirow{2}{*}{ Nomenclature } & \multicolumn{7}{c}{$\mathrm{SiO}_{\mathbf{2}}$ Backbone (mol \%) } \\
\cline { 2 - 8 } & $\mathbf{S i O}_{\mathbf{2}}$ (NF) & $\mathbf{C a O}(\mathbf{N M})$ & $\mathbf{Z n O}(\mathbf{N M})$ & $\mathbf{N a}_{\mathbf{2}} \mathbf{O}(\mathbf{N M})$ & $\mathbf{S r O}_{\mathbf{N M}}$ & $\mathbf{G e O}_{\mathbf{2}}$ (NF) & $\mathbf{N C}$ \\
\hline $\mathrm{KBT01}$ & 0.50 & 0.10 & 0.30 & 0.10 & 0.00 & 0.00 & 2.0 \\
$\mathrm{KBT02}$ & 0.50 & 0.10 & 0.27 & 0.10 & 0.00 & 0.03 & 2.2 \\
$\mathrm{KBT03}$ & 0.50 & 0.10 & 0.24 & 0.10 & 0.00 & 0.06 & 2.4 \\
$\mathrm{BT101}$ & 0.48 & 0.12 & 0.36 & 0.00 & 0.04 & 0.00 & 1.83 \\
\hline
\end{tabular}

\subsection{Cement Handling Characteristics $\left(T_{w}\right.$ and $\left.T_{s}\right)$}

Figure 5a displays the working time $\left(T_{w}\right)$ of the cement series formed form the glasses as the concentration of Ge in the KBT glass phase increased from 0.00 to $0.06 \mathrm{~mol} \%$.

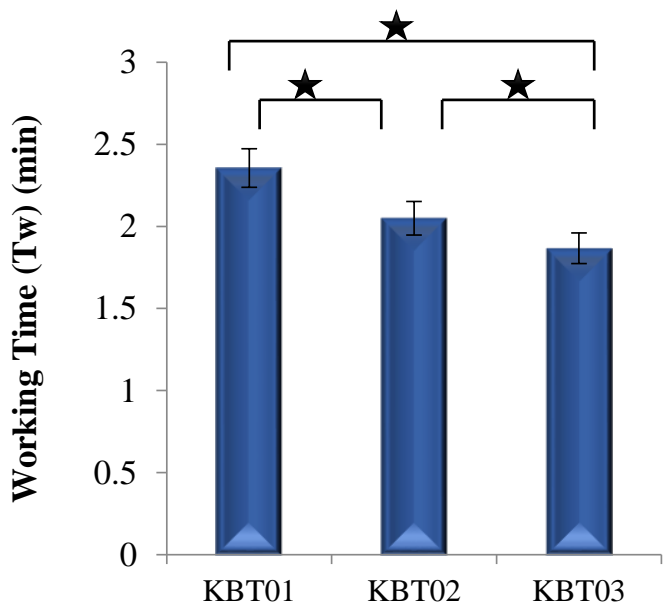

(a)

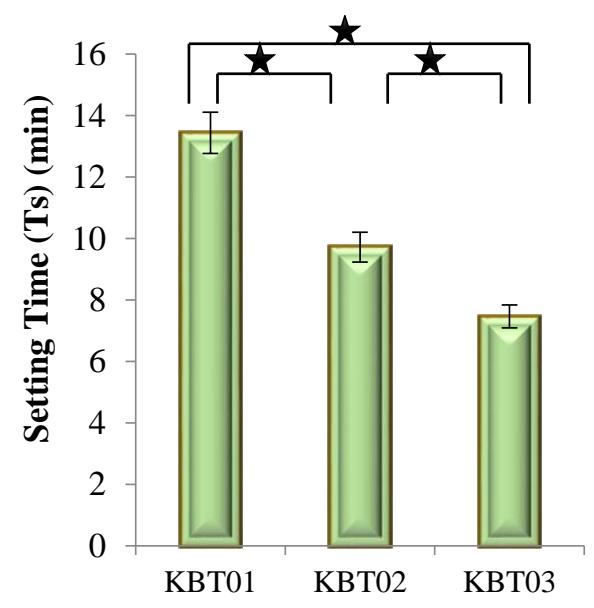

(b)

Figure 5. (a) Working times of the cement series; (b) Net setting times of the cement series. Stars and bars show statistical significance $(p<0.05)$.

As Ge addition in the glasses increased, $T_{w}$ of the cements made from them linearly decreased. Figure $5 \mathrm{~b}$ displays the setting times $\left(T_{s}\right)$ of the cement series, with $T_{s}$ decreasing from $800 \mathrm{~s}$ for KBT01 cement to $450 \mathrm{~s}$ for KBT03 cement. All of these results show a statistically significant difference $(p<0.05)$ with Ge incorporation. The decreasing trends experienced in both $T_{w}$ and $T_{s}$ resulted from the introduction of Ge to the glass phase, which may result in an increased susceptibility to acid 
attack, the glasses releasing more cations into the environment resulting in increased carboxylic (COO-) - metal bonding rates [41]. The introduction of Ge ions, which have a $4^{+}$charge, may also increase the bonding rate of the unbonded COO- molecular chains [30]. The network connectivity (NC) data in Table 5 confirm NC increasing with Ge content.

During the cranioplasty surgical procedure, the surgeon requires adequate time to apply the cement before it begins to set. Cranioplasty procedures, which involve drilling and securing a miniplate with screws, as well as adhering the plate to the bone with cement, have been timed at approximately $8 \mathrm{~min}\left(480 \mathrm{~s}\right.$ ) [42]. A minimum $\mathrm{T}_{w}$ for cements in cranioplasty has not been reported in the literature. However, ISO9917 [36] is a standard that defines rheological properties of water-based cements, such as GPCs, for dental applications, and although it does not specify $T_{w}$ for GPCs, it identifies a range of $T_{s}$ between 1.5 and $6 \mathrm{~min}$ [36]. All cements in this research exhibit $\mathrm{T}_{w}$ greater than $90 \mathrm{~s}$ and $T_{s}$ less than $800 \mathrm{~s}$ and are compliant with ISO9917 [36]. It would be beneficial to secure clinical feedback of these cements with the objective of determining the suitability of their rheology for cranioplasty applications.

\subsection{Compressive $\left(\sigma_{c}\right)$ and Flexural $\left(\sigma_{f}\right)$ Strengths}

$\sigma_{c}$ was evaluated according to ISO9917 [36]. Samples were submerged in distilled water for 1, 7 and 30 days prior to testing.

Figure 6 displays $\sigma_{c}$ recorded for all cement formulations. The compressive strength increased with maturation for each sample set, with the largest increase occurring between 7 and 30 days. The incorporation of Ge in the KBT glass phase also increased compressive strength, with statistical differences occurring between the KBT01 and KBT03 cements at 1 day maturation, and for all cements between 7 and 30 days maturation.

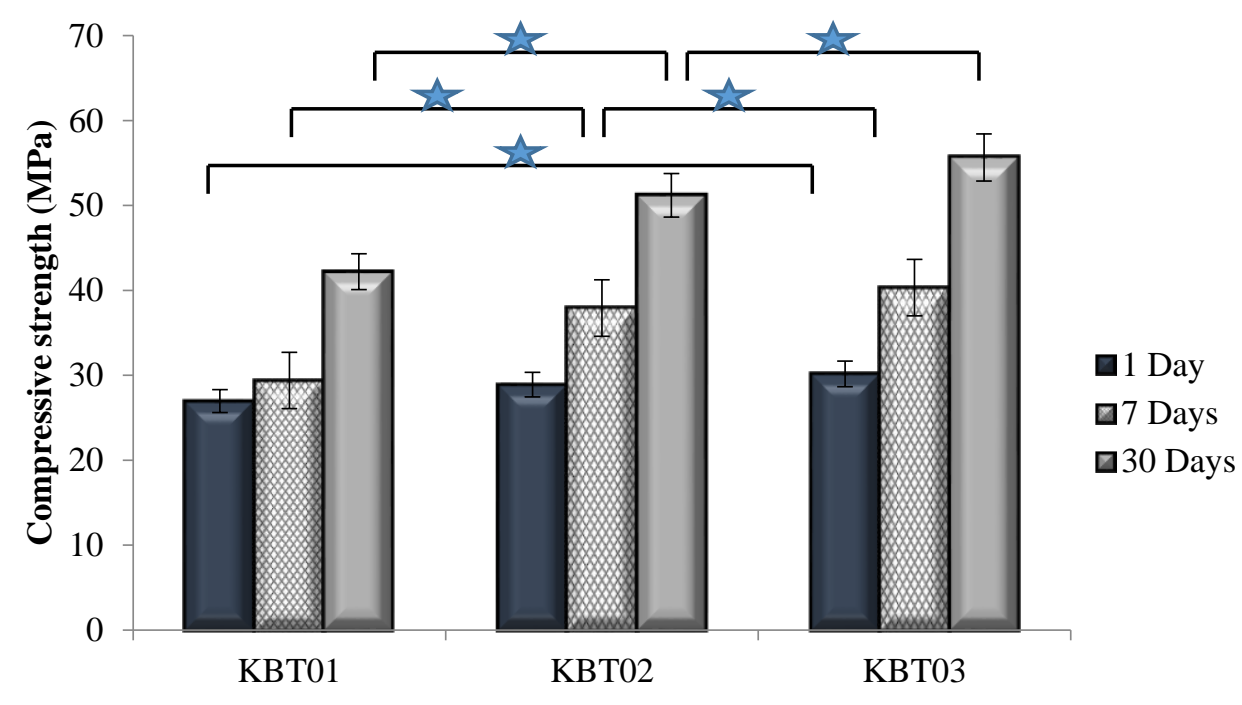

Figure 6. Compressive strengths for the cement series over 1, 7 and 30 days maturation. Stars and bars show statistical significant difference $(p<0.05)$.

Flexural strength testing was conducted. Figure 7 presents the $\sigma_{f}$ results, which exhibited changes in strength with respect to time, with similar trends to $\sigma_{c}$ in terms of maturation and Ge addition. 


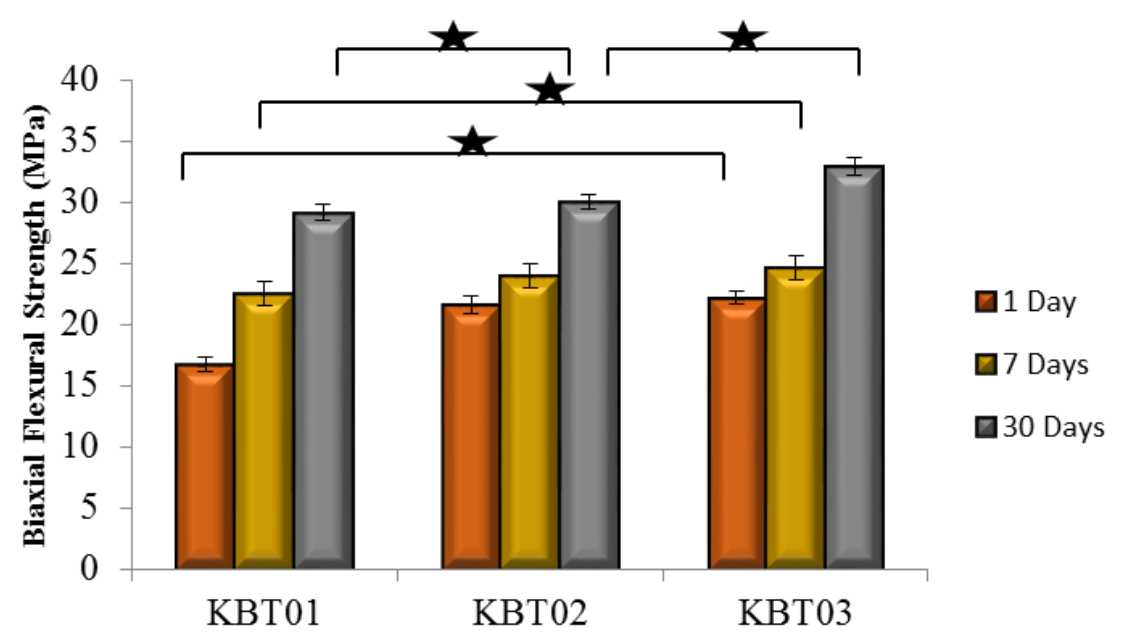

Figure 7. Biaxial flexural strengths for the cement series over 1, 7 and 30 days maturation. Stars and bars show statistical significant difference $(p<0.05)$.

Strength increases with maturation are commonplace with GPCs and are related to the ions released from the glass chelating with the $\mathrm{COO}^{-}$from the acid component over time [43-46], through a continuous acid-base reaction [47]. In addition to maturation, strengths also increased with Ge content. Ge is a $4^{+}$valency ion thus it will bond and increase the network connectivity (NC) of the cement, (Table 5), Hill et al. [48] described the entanglement of polyanion chains during GPC setting and how they limit lateral movement, while interactions with neighboring chains limit longitudinal movement. Thus, it is probable that relations between multivalent $\mathrm{Ge}^{4+}$ ions, or complexes thereof, interrelate with more than two polyanions to increase chain bonding and entanglement thus creating stronger cements [49-51].

\subsection{Tensile Bonding Test}

Figure 8 illustrates the bond strength measurements for the cement series after 0, 1, 7 and 14 days maturation of the bond between the cement samples and bone.

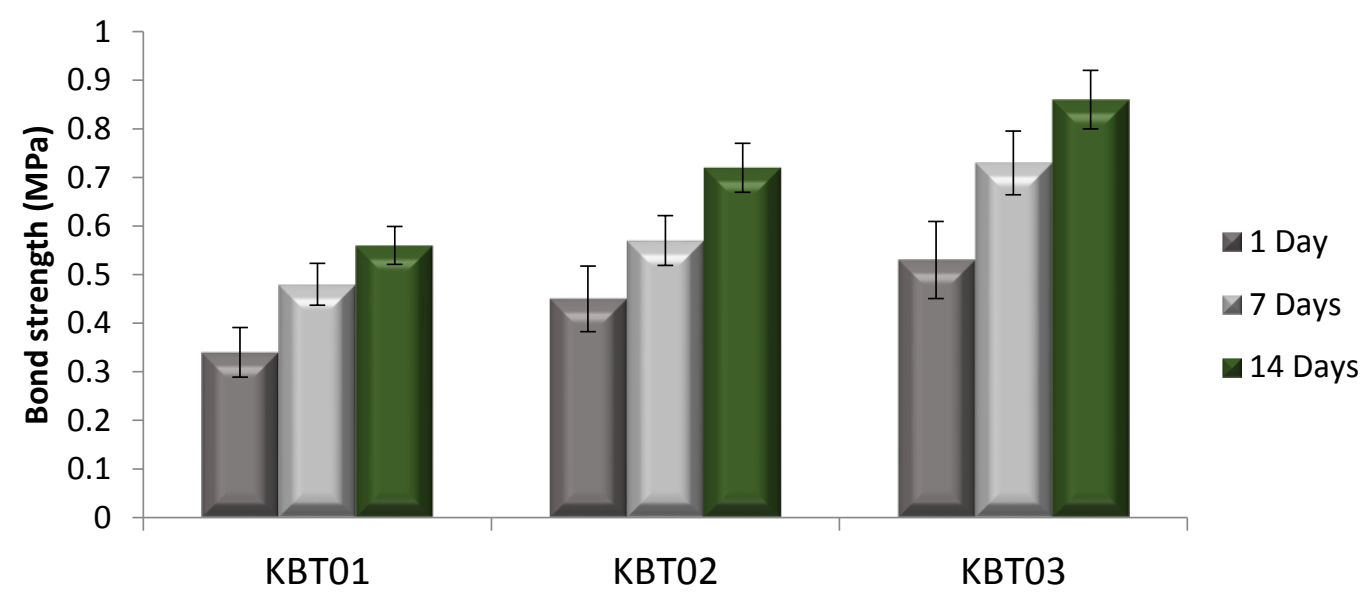

Figure 8. Tensile strength measurements for the bond strength tested over 1, 7, and 14 days.

The bond strength between the cement and bone was found to increase with both Ge content in the glass phase and cement maturation (Figure 8). At 0 and 1 day, failure occured between the cement and bone for each construct, yet the titanium cylinder exhibited traces of cement residue (Figure 9a). This cohesive failure was also evident after 7 days maturation, however, as seen in Figure 9b, small 
parts of the cement remain attached to the bone. After 14 days, failure occured between the Ti cylinder and cement, indicating that the bond strength at the bone/cement interface was greater than that between the Ti cylinder and cement (Figure 9c). Thus, bond strength increased with cement maturation.
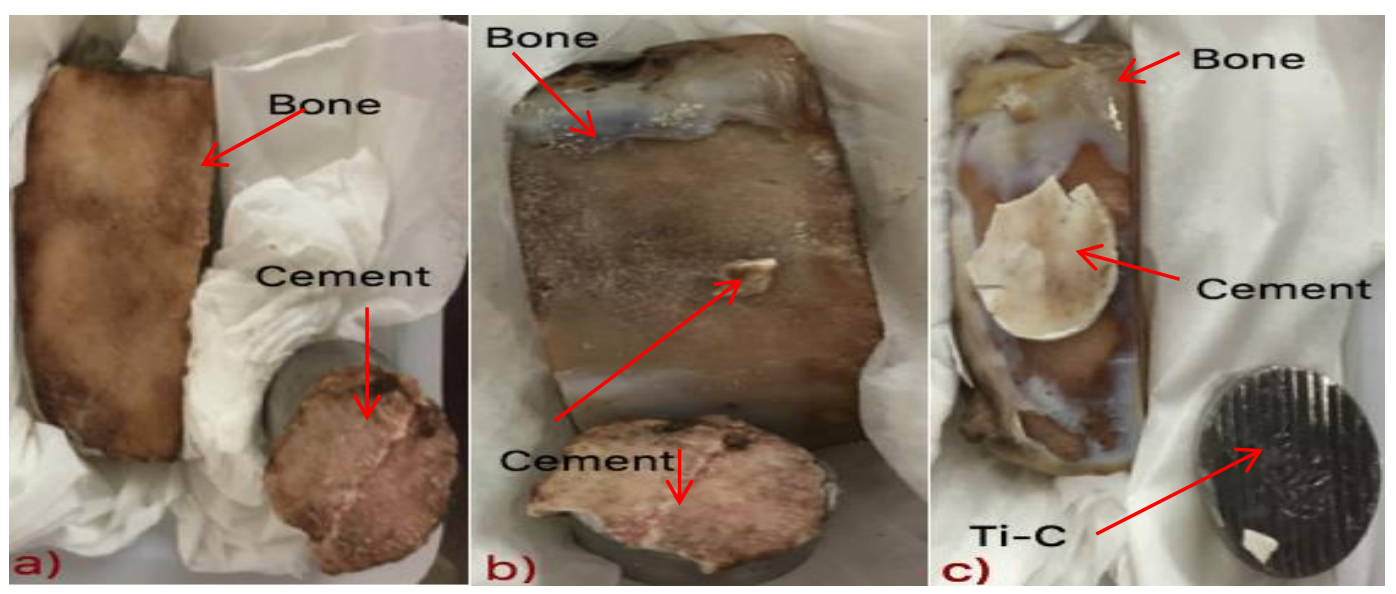

Figure 9. Cement/ovis aries bone constructs after: (a) 0 and 1 day maturation; (b) 7 days maturation; (c) 14 days maturation.

Comparing this experimental data to the literature, where five different screws of different lengths were evaluated for securing a titanium miniplate to hydroxyapatite (HA) blocks [5] in a cranioplasty situation, an average bond strength of $97 \mathrm{~N}$, increasing up to $257 \mathrm{~N}$ with screw length, were reported [5]. After 14 days maturation, the bond strength using the test methodology described here, averaged between 0.53 and $0.86 \mathrm{MPa}(153 \mathrm{~N}$ to $247 \mathrm{~N})$, as shown in Figure 9. From this, the KBT03 cement can be considered to offer similar resistance to pull out to the screw method.

\subsection{Ion Release}

Ion release from the cements were measured cumulatively over 1, 7 and 30 days and are tabulated in Figure 10. As would be expected, ion release ( $\mathrm{Na}, \mathrm{Sr}, \mathrm{Si}, \mathrm{Zn}, \mathrm{Ca}$ and $\mathrm{Ge})$ increased with maturation. However, the incorporation of $\mathrm{Ge}$ into the glass resulted in lower ion release for the $\mathrm{Na}, \mathrm{Sr}, \mathrm{Si}, \mathrm{Zn}$ and Ca ions at the same time point, with the obvious exception of $\mathrm{Ge}$, which, understandably, increases in line with its content in the precursor glass from which it elutes.

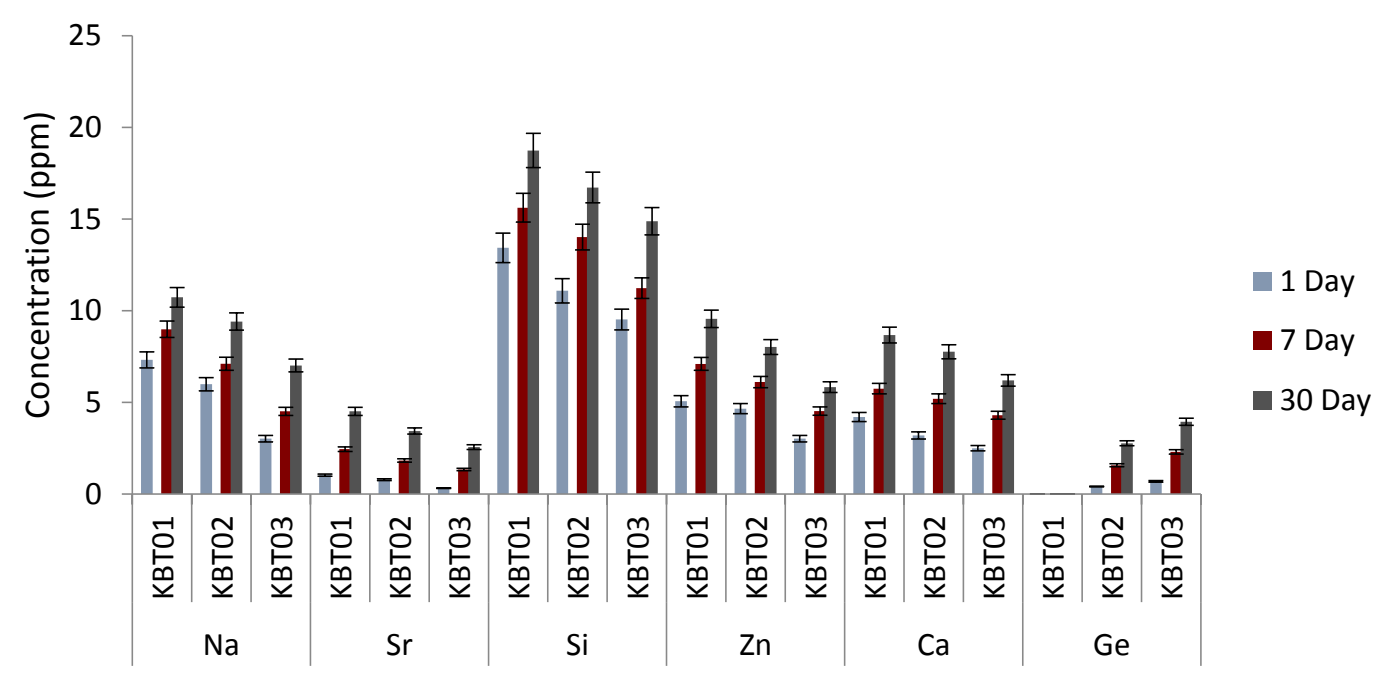

Figure 10. Ion release profiles for the cement series over 1, 7 and 30 days. 
Unsurprisingly, the incorporation of increasing amounts of Ge in the glass phase results in increasing amounts of $\mathrm{Ge}$ ion release recorded from the resultant cements. There is also less $\mathrm{Zn}$ ion release from the cements going through the series as the increased Ge content in the precursor glasses occurs as a result of reduced $\mathrm{Zn}$. However, the quantity of all other ions released from the cements also decreases with increased Ge content, which suggests that $\mathrm{Ge}$ is stabilizing the glass network. As the mechanical properties of the cements increase going through the series it suggests that is the Ge ion, with its $4^{+}$valency, that is dominating the cement setting reaction.

\subsection{Radiopacity (X-ray) -MicroCT}

Radiopacity was evaluated according to the ASTM F640 "Standard Test Methods for Determining Radiopacity for Medical Use" which is applied for monitoring the position of permanently implanted medical devices [52]. It is vital that orthopedic adhesives are radiologically detectable to facilitate long term monitoring [6]. The results of the radiographic testing are shown in Figure 11(Left). The cement is represented by the lighter colored image compared to the Bone Standard Density (BSD), which is represented as a darker color on the X-ray [53]. As shown in Figure 11(Right), the cement densities were higher $\left(1.35\right.$ to $\left.1.57 \mathrm{~g} / \mathrm{cm}^{2}\right)$ than that of the BSD; the radiopacity of which was measured as $1.05 \mathrm{~g} / \mathrm{cm}^{2}$.

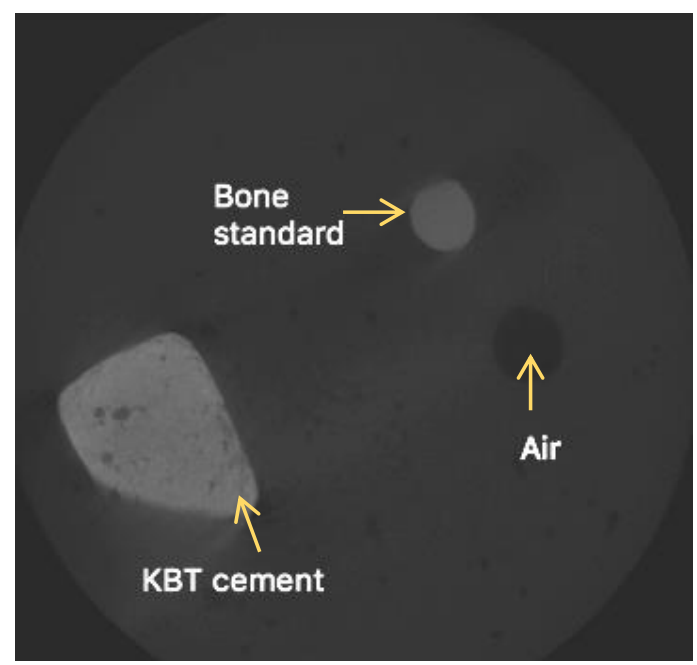

(a)

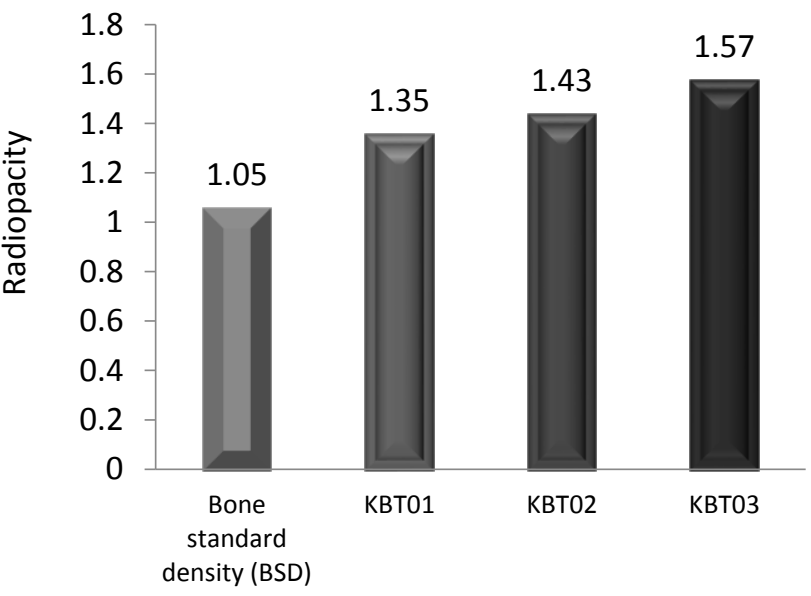

(b)

Figure 11. (a) Radiograph image of the cement sample and SP3 standard; (b) Comparison of the radiopacity of the cements.

Figure 12 describes the setting times and compressive strengths of the Aluminum-free GPCs that have been reported in the literature. In 2008, Boyd and Towler et al. [34] developed an ionomer glass, which substituted $\mathrm{SrO}$ with $\mathrm{CaO}$; the resultant cements recorded considerably shorter setting times ( $<1 \mathrm{~min}$ ) and a maximum compressive strength of $70 \mathrm{MPa}$. The KBT cement is shown to have a longer setting time $(7.5 \mathrm{~min})$ but a slightly lower compressive strength $(56 \mathrm{MP})$ than Boyd and Towler's study. Wren et al. [46] developed an ionomer glass based on the same composition as that of Boyd and Towler but with Ga substituted for $\mathrm{ZnO}$. The setting time of this cement was $9.3 \mathrm{~min}$, similar to that of the cements discussed in this paper. However it recorded a low compressive strength of $6 \mathrm{MPa}$. The setting time for the KBT glass-based cements was found to be comparable to those recorded by Zhang et al. [33] who reported on a cement based on a series of zinc-boron Ge based glasses. However, the compressive strength (36 MPa) reported on Zhang's cements was lower than that recorded on the materials reported here. Dickey et al. [30] also reported on Germanium-glass based GPCs and a further study by Kim et al. [54] considered GPCs based on magnesium/strontium-silicate glasses. Dickey et al. [30] was found to have had a long-setting time of $36 \mathrm{~min}$ while Kim et al. [54] had a setting 
time of $45 \mathrm{~min}$. The strengths and setting times of all of the cements reported in these studies are compared and contrasted in Figure 12.

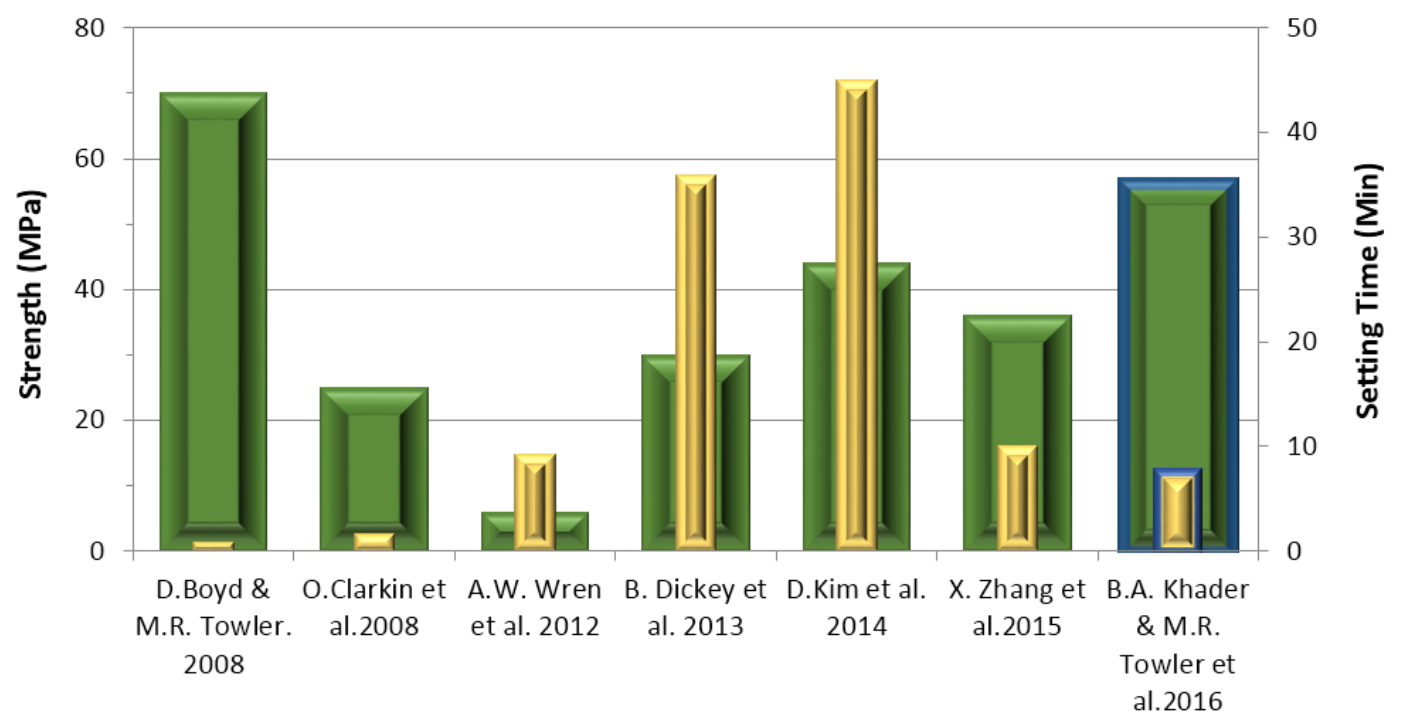

Figure 12. Setting time and compressive strength of aluminum-free GPCs reported in the literature. the blue frame denotes the results of this paper.

\section{Conclusions}

The objective of this research was to determine the influence of Ge substitution for $\mathrm{Zn}$ on the rheological and mechanical properties of a series of glass polyalkenoate cements (GPCs) derived from novel aluminium-free, ionomer glasses and to subsequently evaluate their suitability for cranioplasty applications by the use of a novel bond test. The handling and mechanical properties of the experimental cements are collated in Table 6.

Table 6. Summary of the results from the novel cements.

\begin{tabular}{|c|c|c|c|c|c|c|}
\hline \multirow[t]{2}{*}{ Composition } & XRD & $T_{W} / T_{S}(\mathrm{~s})$ & $\sigma_{c}(\mathrm{MPa})(\mathrm{Min}-\mathrm{Max})$ & $\sigma_{f(\mathrm{MPa})(\mathrm{Min}-\mathrm{Max})}$ & $\begin{array}{c}\mathrm{Ti}^{*} \text {-Bone } \\
(\mathrm{MPa}) \\
\end{array}$ & \multirow{2}{*}{$\begin{array}{c}\text { Radiopacity } \\
\left(\text { Density g/cm }{ }^{2}\right)\end{array}$} \\
\hline & Analysis & $p<0.05$ & $p<0.05$ & $p<0.05$ & (Min-Max) & \\
\hline КВТ01 & Amorphous & $141 / 806$ & $27-42$ & $17-29$ & $0.34-0.56$ & 1.35 \\
\hline КВT02 & Amorphous & $123 / 583$ & $29-51$ & $21-30$ & $0.45-0.72$ & 1.43 \\
\hline КВТ03 & Amorphous & $112 / 448$ & $31-56$ & $22-33$ & $0.53-0.86$ & 1.57 \\
\hline
\end{tabular}

$\mathrm{Ti}^{*}$ is the Ti cylinder.

The KBT03 glass, when mixed with the other components, produced a cement that has handling properties acquiescent with ISO9917 [36] guidelines while all cements of the KBT glass series set within the required time as outlined by ISO5833 [55] for orthopedic cements. Although these standards are designed for evaluating cements for cranioplasty applications, they do offer a window into the suitability of properties of cements for clinical applications. Compressive and flexural strengths of cements were found to be dependent on both the presence and amount of Ge in the glass phase and maturation time. Ion release profiles were also dependent on the presence of $\mathrm{Ge}$ in the glass phase, resulting in a smaller amount of $\mathrm{Si}, \mathrm{Zn}, \mathrm{Ca}, \mathrm{Na}$ and $\mathrm{Sr}$ ions released from KBT02 and KBT03, presumably due to the addition of $\mathrm{Ge}$. MicroCT was able to distinguish radiographically between a bone standard and the cements, radiopacity increasing with the addition of Ge (Figure 11, right). KBT03 appeared to have potential for cranioplasty as the bond strengths recorded were within the range reported for screws applied in the clinical application [5]. 


\section{Limitations of the Study}

There are a lack of current ISO/ASTM standards for cranioplasty, meaning that it was not possible to target the aims of the research against such standards. Additionally, no biocompatibility data was recorded for these materials to date; this will be addressed in future studies.

Acknowledgments: The authors gratefully acknowledge the financial assistance of the Collaborative Health Research Project, CIHR/NSERC (315694-DAN). The authors would also like to thank Alan Machin and Adel Alhalawani (both Ryerson University, Toronto, ON, Canada) for aspects of data collection.

Author Contributions: B.K. and M.T. conceived and designed the experiments; B.K. performed the experiments; B.K. and M.T. analyzed the data; M.T and S.P. contributed reagents/materials/analysis tools; B.K, D.C and M.T. wrote the paper.

Conflicts of Interest: The authors declare no conflict of interest.

\section{References}

1. Beals, S.P.; Munro, I.R. The use of miniplates in craniomaxillofacial surgery. Plast. Reconstr. Surg. 1987, 79, 33-38. [CrossRef] [PubMed]

2. Simpson, D. Titanium in cranioplasty. J. Neurosurg. 1965, 22, 292-293. [CrossRef] [PubMed]

3. Ono, I.; Suda, K.; Tateshita, T.; Gunji, H.; Kaneko, F. Analysis of strength and bone conduction of hydroxyapatite ceramics. J. Jpn. Plast. Reconstr. Surg. 1993, 13, 561-571.

4. Ono, I.; Gunji, H.; Suda, K.; Kaneko, F.; Yago, K. Orbital reconstruction with hydroxyapatite ceramic implants. Scand. J. Plast. Reconstr. Hand Surg. 1994, 28, 193-198. [CrossRef]

5. Tanaka, Y. Development of titanium fixation screw for hydroxyapatite osteosynthesis (APACERAM). Surg. Neurol. 2008, 70, 545-549. [CrossRef] [PubMed]

6. Boyd, D. Zinc-Based Glass Polyalkenoate Cements for Skeletal Applications. PhD. Thesis, College of Engineering, University of Limerick, Limerick, Ireland, 2005.

7. Cho, Y.R.; Gosain, A.K. Biomaterials in craniofacial reconstruction. Clin. Plast. Surg. 2004, 31, $377-385$. [CrossRef] [PubMed]

8. Berry, J.P. Surface characteristics of fractured poly (methyl methacrylate). Nature 1960, 185, 91-92. [CrossRef]

9. James, S.P.; Jasty, M.; Davies, J.; Piehler, H.; Harris, W.H. A fractographic investigation of PMMA bone cement focusing on the relationship between porosity reduction and increased fatigue life. J. Biomed. Mater. Res. 1992, 26, 651-662. [CrossRef] [PubMed]

10. Kricun, R.; Chovanes, G.I.; Shoemaker, E.I. CT and MR appearance of cervical acrylic struts. J. Comput. Assist. Tomogr. 1991, 15, 519-521. [CrossRef] [PubMed]

11. Remsen, K.; Lawson, W.; Biller, H.F. Acrylic frontal cranioplasty. Head Neck Surg. 1986, 9, 32-41. [CrossRef] [PubMed]

12. Persing, J.A.; Cronin, A.J.; Delashaw, J.B.; Edgerton, M.T.; Henson, S.L.; Jane, J.A. Late surgical treatment of unilateral coronal synostosis using methyl methacrylate. J. Neurosurg. 1987, 66, 793-799. [CrossRef] [PubMed]

13. Wren, A.; Boyd, D.; Towler, M.R. The processing, mechanical properties and bioactivity of strontium based glass polyalkenoate cements. J. Mater. Sci. Mater. Med. 2008, 19, 1737-1743. [CrossRef] [PubMed]

14. Wong, L.; Manson, P.N. Rigid mesh fixation for alloplastic cranioplasty. J. Craniofac. Surg. 1994, 5, $265-269$. [CrossRef] [PubMed]

15. Replogle, R.E.; Lanzino, G.; Francel, P.; Henson, S.; Lin, K.; Jane, J.A. Acrylic cranioplasty using miniplate struts. Neurosurgery 1996, 39, 747-749. [CrossRef] [PubMed]

16. Gibbons, K.J.; Hicks, W.L., Jr.; Guterman, L.R. A technique for rigid fixation of methyl methacrylat cranioplasty: The vault-locking method. Surg. Neurol. 1999, 52, 310-315. [CrossRef]

17. Raja, A.I.; Linskey, M.E. In situ cranioplasty with methylmethacrylate and wire lattice. Br. J. Neurosurg. 2005, 19, 416-419. [CrossRef] [PubMed]

18. Blum, K.S.; Schneider, S.J.; Rosenthal, A.D. Methyl methacrylate cranioplasty in children: Long-term results. Pediatr. Neurosurg. 1997, 26, 33-35. [CrossRef] [PubMed]

19. De Santis, R.; Gloria, A.; Ambrosio, L. Materials and Technologies for Craniofacial Tissue Repair and Regeneration. Top. Med. 2010, 16, 1-6. 
20. Donkerwolcke, M.; Burny, F.; Muster, D. Tissues and bone adhesives-historical aspects. Biomaterials 1988, 19, 1461-1466. [CrossRef]

21. Towler, M.R.; Kenny, S.; Boyd, D.; Pembroke, T.; Buggy, M.; Hill, R.G. Zinc ion release from novel hard tissue biomaterials. Biomed. Mater. Eng. 2004, 14, 565-572. [PubMed]

22. Endotherapeutics: Serenocem Ear Cement and Granules. Available online: http:/ / www.endotherapeutics.com.au/serenocem (accessed on 5 February 2016).

23. Invotec International ${ }^{\circledR}:$ Serenocem ${ }^{\mathrm{TM}}$ Ostologic Cement. Available online: http://www.mundinc.com/ uploads/serenocem_otologic_cement.pdf (accessed on 5 February 2016).

24. Wren, A.W.; Kidari, A.; Cummins, N.M.; Towler, M.R. A spectroscopic investigation into the setting and mechanical properties of titanium containing glass polyalkenoate cements. J. Mater. Sci. Mater. Med. 2010, 21, 2355-2364. [CrossRef] [PubMed]

25. Sawai, J. Quantitative evaluation of antibacterial activities of metallic oxide powders $(\mathrm{ZnO}, \mathrm{MgO}$ and $\mathrm{CaO})$ by conductimetric assay. J. Microbiol. Methods 2003, 54, 177-182. [CrossRef]

26. Catelan, A.; Padilha, A.C.; Salzedas, L.M.; Coclete, G.A.; dos Santos, P.H. Effect of Radiotherapy on the Radiopacity and Flexural Strength of a Composite Resin. Acta Odontol. Latinoam. 2008, 21, 159-162. [PubMed]

27. Boyd, D.; Towler, M.R.; Watts, S.; Hill, R.G.; Wren, A.W.; Clarkin, O.M. The role of $\mathrm{Sr}^{2+}$ on the structure and reactivity of $\mathrm{SrO}-\mathrm{CaO}-\mathrm{ZnO}-\mathrm{SiO}_{2}$ ionomer glasses. J. Mater. Sci. Mater. Med. 2008, 19, 953-957. [CrossRef] [PubMed]

28. Clarkin, O.; Boyd, D.; Towler, M.R. Comparison of failure mechanisms for cements used in skeletal luting applications. J. Mater. Sci. Mater. Med. 2009, 20, 1585-1594. [CrossRef] [PubMed]

29. Varshneya, A.K. Fundamentals of Inorganic Glasses, 1st ed.; Gulf Professional Publishing Academic Press: Boston, MA, USA, 1994.

30. Dickey, B.; Kehoe, S.; Boyd, D. Novel adaptations to zinc-silicate glass polyalkenoate cements: The unexpected influences of germanium based glasses on handling characteristics and mechanical properties. J. Mech. Behav. Biomed. Mater. 2013, 23, 8-21. [CrossRef] [PubMed]

31. Dickey, B.; Saffary, J.; Dickinson, V.; Kehoe, S.; Abraham, R.J.; Boyd, D. Development and evaluation of an inherently radiopaque, adhesive bone cement for vertebroplasty. J. Vasc. Interv. Radiol. 2013, 4, S33. [CrossRef]

32. Dickey, B.; Lee, A.; Zhang, X.; Boyd, D. The effect of composition and annealing on the properties of aluminum free GPCs: A preliminary evaluation. Funct. Mater. Lett. 2014, 129, 191-194. [CrossRef]

33. Zhang, X.; Werner-Zwanziger, U.; Boyd, D. Composition-structure-property relationships for non-classical ionomer cements formulated with zinc-boron germanium-based glasses. J. Biomater. Appl. 2015, 29, 1203-1217. [CrossRef] [PubMed]

34. Boyd, D.; Clarkin, O.M.; Wren, A.W.; Towler, M.R. Zinc-based glass polyalkenoate cements with improved setting times and mechanical properties. Acta Biomater. 2008, 4, 425-431. [CrossRef] [PubMed]

35. ISO 9917-1 Dentistry-Water-Based Cements-Part 1: Powder/Liquid Acid-Base Cements; ISO: Geneva, Switzerland, 2007.

36. ISO 9917 Dentistry-Water-Based Cements-Part 1: Powder/Liquid Acid-Base Cements; ISO: Geneva, Switzerland, 1991.

37. Williams, J.A.; Billington, R.W.; Pearson, G.J. The effect of the disc support system on biaxial tensile strength of a glass ionomer cement. Dent. Mater. 2002, 18, 376-379. [CrossRef]

38. ASTM B348-13 Standard Specification for Titanium and Titanium Alloy Bars and Billets; ASTM International: West Conshohocken, PA, USA, 2013.

39. ASTM B265-15 Standard Specification for Titanium and Titanium Alloy Strip, Sheet, and Plate; ASTM International: West Conshohocken, PA, USA, 2015.

40. Prentice, L.H.; Tyas, M.J.; Burrow, M.F. The effect of mixing time on the handling and compressive strength of an encapsulated glass- ionomer cement. Dent. Mater. 2005, 21, 704-708. [CrossRef] [PubMed]

41. Wren, A.W.; Hansen, J.P.; Hayakawa, S.; Towler, M.R. Aluminium-free glass polyalkenoate cements: Ion release and in vitro antibacterial efficacy. J. Mater. Sci. Mater. Med. 2013, 24, 1167-1178. [CrossRef] [PubMed]

42. Broaddus, W.C.; Holloway, K.L.; Winters, C.J.; Bullock, M.R.; Graham, R.S.; Mathern, B.E.; Ward, J.D.; Young, H.F. Titanium miniplates or stainless steel wire for cranial fixation: A prospective randomized comparison. J. Neurosurg. 2002, 96, 244-247. [CrossRef] [PubMed]

43. Boyd, D.; Towler, M.R. The Processing Mechanical Properties and Bioactivity of Zinc Based Glass ionomer Cements. J. Mater. Sci. Mater. Med. 2005, 16, 843-850. [CrossRef] [PubMed]

44. DeBarra, E.; Hill, R.G. Influence of alkali metal ions on the fracture properties of glass polyalkenoate (ionomer) cements. Biomaterials 1998, 19, 495-502. [CrossRef] 
45. Clarkin, O.; Boyd, D.; Towler, M.R. Strontium-based Glass Polyalkenoate Cements for Luting Applications in the Skeleton. J. Biomater. Appl. 2010, 24, 483-502. [CrossRef] [PubMed]

46. Wren, A.W.; Coughlan, A.; Placek, L.; Towler, M.R. Gallium containing glass polyalkenoate anti-cancerous bone cements: Glass characterization and physical properties. J. Mater. Sci. Mater. Med. 2012, 23, 1823-1833. [CrossRef] [PubMed]

47. Wilson, A.D.; Nicholson, J.W. Acid-Base Cements_-Their Biomedical and Industrial Applications (Chemistry of Solid State Materials); West, A.R., Baxter, H., Eds.; Cambridge University Press: Cambridge, UK, 1993.

48. Hill, R.G. The fracture properties of glass polyalkenoate cements as a function of cement age. J. Mater. Sci. 1993, 28, 3851-3858. [CrossRef]

49. Barkema, G.T.; Panja, D.; van Leeuwen, J.M.J. Structural modes of a polymer in the repton model. J. Chem. Phys. 2011, 134, 154901. [CrossRef] [PubMed]

50. Rubinstein, M. Discretized model of entangled-polymer dynamics. Phys. Rev. Lett. 1987, 59, $1946-1949$. [CrossRef] [PubMed]

51. McLeish, T.C.B. Tube theory of entangled polymer dynamics. Adv. Phys. 2002, 51, 1379-1527. [CrossRef]

52. ASTM F640-12: 2012 Standard Test Methods for Determining Radiopacity for Medical Use; ASTM International: West Conshohocken, PA, USA, 2012.

53. Radiology Masterclass: Basics of X-ray Physics. Available online: http:/ /www.radiologymasterclass.co.uk/ tutorials/physics/X-ray_physics_densities.html (accessed on 14 June 2015).

54. Kim, D.A.; Abo-Mosallam, H.A.; Lee, H.Y.; Kim, G.R.; Kim, H.W.; Lee, H.H. Development of a novel aluminum-free glass ionomer cement based on magnesium/strontium-silicate glasses. Mater. Sci. Eng. C Mater. Biol. Appl. 2014, 42, 665-671. [CrossRef] [PubMed]

55. ISO 5833:1992 Implants for Surgery Acrylic Resin Cements; ISO: Geneva, Switzerland, 1992.

(C) 2016 by the authors; licensee MDPI, Basel, Switzerland. This article is an open access article distributed under the terms and conditions of the Creative Commons by Attribution (CC-BY) license (http:/ / creativecommons.org/licenses/by/4.0/). 